\title{
ETIOLOGY OF CHRONIC NON-ALLERGIC URTICARIA
}

\author{
S. Racheva \\ MedicalUniversity - Varna, Clinic of Dermatology and Venerology \\ Reviewed by: Assoc. Prof. Zh. Georgieva, MD, PhD
}

\begin{abstract}
The chronic non-allergic urticaria / $\mathrm{CNU} /$ is a frequent malady; almost $25 \%$ of a given population has suffered incidents of Urticaria. Often the causes provoking it remain undiscovered and Urticaria is defined as idiopathic. Besides this form, CNU includes physical Urticaria and urticarial reactions, the secondary causes of which are other somatic disorders (chronic infections, autoimmune diseases, malign proc-esses etc.) The effective treatment of $\mathrm{CNU}$ is set after precise etiological clarification. The research includes 122 patients with $\mathrm{CNU}$, tested and viewed as having a somatic disorder, physical outside stimuli provoking the urticaria; as allergic reactions to the usual sensibilizing factors are excluded. With 113 of the patients the etiology of the $\mathrm{CNU}$ was clarified: in $55.7 \%$ of them the urticaria was connected with other somatic disorders (in $69.1 \%$ - chronic infection, and in $26.4 \%$ - with autoimmune disease). In $36.8 \%$ of the tested patients various forms of physical urticaria were proved $(33.3 \%$ - cholinergic urticaria, $24.4 \%$ - cold urticaria, $15.5 \%$ - delayed pressure urticaria, $11.1 \%$ - solar urticaria). In $7.3 \%$ of the cases the urticaria was diagnosed as idiopathic. The conclusions drawn predetermine the right choice of the respective therapy and prophylactics.
\end{abstract}

Keywords: Chronic Urticaria, Physical Urticaria, Cholinergic Urticaria, Non-allergic Urticaria, delayed pressure urticaria, cold urticaria, solar urticaria

The chronic non-allergic urticaria /CNU/ is a frequent malady; almost $25 \%$ of a given population has suffered incidents of urticarial reaction (19). It is a syn-drome of the "nerve mastoid cell". It is associated with infections, autoimmune diseases, metabolic disorders, malign processes and physical stimuli. The chronic urticaria includes various forms of physical urticaria (PU), idiopathic urticaria (IU) and secondary urticarial reactions, caused by other somatic disor-ders.

The cases of urticaria with a length of over 6 weeks and with undiagnosed cause are defined as IU. IU covers $25-45 \%$ of all urticarial reactions and recent research shows its autoimmune genesis (10).

PU includes the subgroups of chronic urticaria, shows frequency between $14 \%$ and $17 \%(23,17)$, and is provoked by physical stimuli, such as trauma, pressure, light, cold, heat, water, vibrations .

CNU causes considerable therapy problems due to its various forms and to the mul-tidirectional treatment. This requires maximum efforts towards the etiological clari-fication of each concrete case and the personified and adequate treatment approach.

The present research aims to clarify the etiology of the $\mathrm{CNU}$ of a group of patients, tested and observed in the Clinic of Skin and Venereal Diseases - Varna.

\section{MATERIAL AND METHODS}

The research covers 122 patients with CNU, tested and observed for a period of five years in an allergology surgery. De- pending on the clinic picture and the medical his-tory, as well as the clinic observation, the patients were tested for somatic disorder. With those with data of PU provocative tests were held with an ice cube (with expo-sure from 1 to 10 minutes) and a single and repeated pressure test. All patients were tested for allergic reactions to atopens, bacterial and food allergies, pollens in order to exclude allergic genesis of the urticaria.

\section{RESULTS AND DISCUSSION:}

In 113 of the tested patients, etiological clarification of CNU was achieved (table 1): in $55.7 \%$ of the cases the urticaria was connected with another somatic disorder, in $36.8 \% \mathrm{PU}$ was proven, and in $7.3 \%$ of the patients the urticaria was diagnosed as idiopathic due to the lack of concrete data for its causes.

Table 1. Etiology of the Chronic Urticaria (122 patients)

\begin{tabular}{||l|c|c||}
\hline \hline Etiologic Diagnosis & Number of Patients & \% \\
\hline $\begin{array}{l}\text { Urticaria connected } \\
\text { with other disorders }\end{array}$ & 68 & 55.7 \\
\hline Physical Urticaria & 45 & 36.8 \\
\hline Idiopathic Urticaria & 9 & 7.3 \\
\hline Total & 122 & 100 \\
\hline \hline
\end{tabular}


The data received about the frequency of $\mathrm{CNU}$, associated with other diseases corre-sponds to that in literature. Montureux P. (1988) establishes chronic infections in $81 \%$ of the cases, but there are authors pointing to a lower percentage (23). The fre-quency of the PU in the research shows a percentage higher than that in literature (23), while that of IU - lower.

The patients with CNU connected with another disease showed the following distri-bution (table 2): in 47 patients $(69.11 \%)$ a connection with chronic infections (with two people - rheumatism, with 10 - intestinal parasites, with 5 toxoplasmosis, with 7 - hepatitis $C$ virus infection, with 7 Heliobacter pylori-infection and with 16 - with other banal infections). In 18 patients (26.7\%) CNU was connected with autoimmune diseases (12 - with autoimmune thyroditis, 1 - with Lupus erythema-todes, 1 - with Dermatomyoisits, 4 - with other endocrine diseases). In two patients $(2.9 \%)$ the urticaria was on the background of a malign process (mediastinal tumors) and in one patient $(1.4 \%)$ a hereditary angioedema was discovered.

Table 2. Etiology of the Chronic Non-allergic Urticaria, connected with other diseases

\begin{tabular}{||l|c|c||}
\hline \multicolumn{1}{|c|}{ Etiologic Diagnosis } & Number of Patients & $\mathbf{\%}$ \\
\hline $\begin{array}{l}\text { Urticaria connected with chronic } \\
\text { infections }\end{array}$ & 47 & 69.1 \\
\hline $\begin{array}{l}\text { Urticaria connected with } \\
\text { autoim-mune disorders }\end{array}$ & 18 & 26.4 \\
\hline $\begin{array}{l}\text { Urticaria connected with malign } \\
\text { processes }\end{array}$ & 2 & 2.9 \\
\hline $\begin{array}{l}\text { Urticaria connected with genetic } \\
\text { factors }\end{array}$ & 1 & 1.4 \\
\hline Total & 68 & 100 \\
\hline \hline
\end{tabular}

The variety of chronic infections, causing CNU which were established during the research correlate with those in literature: $\mathrm{CNU}$, associated with hepatitis $\mathrm{C}$ virus infection $(28,18)$, with rheumatism (19), with intestinal parasites (11). A number of authors point to the direct and indirect role of Helicobacter pylori infection in the development of CNU $(27,30)$.

The connection CNU - autoimmune or another endocrine disorder is discussed at length in literature (9) as the autoimmune thyroditis is named as the most frequent urticaria cause (9), as well as the tendency of an increase of these cases (13). The urticaria is assumed to be an autoimmune disorder (12), proven in over $25 \%$ of the cases (11). Many authors find in $45-50 \%$ of the $\mathrm{CNU}$ a skin autoimmune disorder (14). The CNU is rarely connected with a malign process; the risk of such a connec-tion is 3\% (26).

The physical forms of the CNU in the research showed the following distribution (Table 3): U. cholinergica was found in 15 patients $(33.3 \%)$, U. a'frigore - in 11 pa-tients (24.4\%), U a'pressionem I in 7 patients (15.5\%), symptom- atic dermo-graphism - in 7 patients $(15.5 \%)$ and $U$. solar in 5 patients $(11.1 \%)$.

Table 3. Etiology of the Physical Forms of Chronic Non-Allergic Urticaria (45 patients)

\begin{tabular}{||l|c|c||}
\hline \hline Etiological Diagnosis & Number of Patients & $\%$ \\
\hline U. cholinergica & 15 & 33.3 \\
\hline U. a'frigore & 11 & 24.4 \\
\hline U a'pressionem & 7 & 15.5 \\
\hline $\begin{array}{l}\text { Symptomatic } \\
\text { dermographism }\end{array}$ & 7 & 15.5 \\
\hline U. Solar & 5 & 11.1 \\
\hline Total & 45 & 100 \\
\hline \hline
\end{tabular}

The Cholinergic Urticaria according to literature data varies from $4 \%$ (8) to $56 \%$ (17) among all forms of chronic urticaria. A number of authors find it more often in the atopens (15) than in the general population. The agents provoking it could be various: stress (15), perspiration (15), physical exertion (31), taste stimuli (29), haemodialysis (2).

Urticaria a'pressionem is described as a form of PU, with frequency of 5\% (8) among adults and $24 \%$ among children, more often met in the atopens, mediated by histamine, appearing quickly after pressure and with wheals duration of 30 minutes. Another form of Urticaria a'pressionem is the urticaria caused by pressure - delayed type when pressure on the skin makes the mastocytes join the process, but with an unknown mediator $(7,3)$ and probably a cellular-based reaction (3). This type of ur-ticaria appears 4 hours after the appliance of the physical stimulus and lasts up to 3 days. The data received from the research of Urticaria a'pressionem (15.5\%) in-cludes both types of pressure urticaria reactions. It has to be taken into account that the delayed type pressure urticaria very often combines with other forms of chronic urticaria; with IU (10), with cold $2 \%$ and with cholinegic - $11 \%(1)$, as well as with delayed dermographism $(1,5)$.

The cold urticaria is described as inherited (16) or acquired (24). It can be associated with cryogobulinemia (20), associated with vasculitis (6) or virus infections (4).

The solar urticaria is among $4 \%$ to $5.3 \%$ of the cases of the photodermatoses (25), more often associated with atopy. It is viewed as an IgE mediated reaction, caused by photo allergens with various length of the waves (21) or by nonspecific photo allergens as photo protection or anti-microbic means, fragrances, medicaments as promethazin, chlorpromazine.

\section{CONCLUSIONS}

With the etiology of the CNU considerable importance have the chronic infections, autoimmune diseases and different physical stimuli (cold, pressure, physical exer-cises, sun light). The detail clarification of the causes of the urti- 
caria in every single case determines the suitable and adequate methods and possible therapy.

\section{BIBLIOGRAPHY}

1. Barlow, R J, K. Watson, A.K. Black,M.W. Greaves, Diagnosis and incidence of delayed pressure urticaria in patients with chronic urticaria, J. Am. Acad Dermatol, 199, 29 (6), 954- 8.

2. Confino-Cohen, R, A. Goldberg, E. Magen, Y.A. Mekori, Haemodialisis-induced rash: a unique case of chronic urticaria, J Allergy Clin Immunol, 1995, 95(6), 1002 - 4.

3. Czarnetzki, BM, J. Meetken, G. Kolde, E.B. Brocker, Morpholgy of the cellular infiltrate in delayed pressure urticaria, J Am Dermatol,1985,12(2), $253-9$.

4. Doeglas, HMG., W.J.Rijnten, F.P. Schroder, J. Schirm, Cold urticaria and virus infections: A clinical and serological study in 39 patients, $\mathrm{Br} \mathrm{J}$ Dermatol,1986,114,3,311-318.

5. Dover, JS, A.K. Bleck, A.M. Word, M.W. Greaves, Delayed pressure urticaria. Clinical features, laboratory investigations, and response to therapy of 44 patients, J Am Acad Dermatol, 1989,21(3), 588-9.

6. Eady, RAJ, T.M. Keahey, R. Sibbald, A. Kobza Black, Clin Exp Darmatol, 1981, 6, 4, 355-366.

7. Esten , SA, C.W.Yung, Delayed pressure urticaria: an investigation of some parameters of lesion induction, J Am Acad Dermatol, 1981, 5(1), 25-31.

8. Giam, YC, V.S. Rajan, An approach to urticaria, Ann Acad Med Singapore, 1983, 12(1), 74-80.

9. Giminez-Arnau, A, R.M. Pojol-Vallverde, J.G. Camarasa, 10-th Congress of European Academy of Dermatology \& Venerology, Munich, 10-14 October 2001.

10. Grattan, CE, D.M. Francis, N.G. Slater, R.J. Barlow, M.W.Greaves, Plasmapheresis for severe, unremitting, chronic urticaria, Lancet, 1992, 2, 339, 8001, 1078-80.

11. Greaves, M, Chronic urticaria, J Allergy Clin Immunol, 2000, 105(4), 664-72.

12. Ferrer, M,J.P. Kinet,A.P. Kaplan, Comparative studies of functional and binding assays of IgE anti-Fc (epsilon RIalpha(alpha-subunit) in chronic urticaria, J Allergy Clin Immunol,1998, 101(5), 672-6.

13. Heymann,WR, Chronic urticaria and angioedema associated with thyrid autoimmunity: review and therapeutic implications, J Am Acad Dermatol, 199, 40(2pt1), 229-32.

14. Hide, M, D.M. Francis, C.E.Grattan, J. Hakimi, J.P. Kochan, M.W. Greaves, Autoantibodies against the hige-affinity IgE receptor as a cause of histamine release in chronic urticaria,
New England Jornal of Medicine, 1993, 328 (22), 1599-604.

15. Hirschmann, JV, F. Lawlor, J.S. Englich, J.B. Louback, R. K. Winkelmann, M. W. Greaves, Cholinergic urticaria. A clinical and histologic study, Arch Dermatol, 1987, 123(4), 462-7.

16. Hoffman, HM, A.A. Wanderer, D.H. Broide, Familial cold autoinflamatory syndrome: phenotype and genotype of an autosomal dominant periodic fever, J Allergy Clin Immunol, 2001, 108 (4), 615-20.

17. Humphreys, F, J.A. Hunter, The characteristics of urticaria in 390 patients, Br J Dermatol, 1998, 138(4), 635-8.

18. Krengel, S, B. Tebbe, S. Goerdt, M. Stoffler-Meilick, C.E. Orfanos, Hepatitis C virus- associated dermatoses: a review, Hautarzt, 1999, 50(9), 629-36.

19. Kulp-Shorten, CL, J.P.Callen, Urticaria, angioedema, and rheumatologic diseases, Rheum Dis Clin North Am, 1996, 22 (1), 95-115.

20. Mittelbach, F, Kalturticaria and Purpura bey Kryoglobulinamie, Z Hautkrankh, 1987, 62,6,48, 496.

21. Miyauchi, H, T. Horio, Detection of action, inhibition and augmentation spectra in solar urticaria, Dermatology, 1995, 191(4), 286-61.

22. Montureux, P, Acute urticaria in infancy and early childhood: a prospective study, Arch Dermatol, 1988, 134(3), 319-23.

23. Nettis, E, A. Pannofino, C. D'Aprile, A. Ferrannini, A. Tursi, Clinical and aetiological aspects in Urticaria and angio-oedema, Br J Dermatol, 2003, 148(3), 501-8.

24. Pazzaque Ahmed, A, R. Moy, Acquirid cold urticaria, Int J Dermatol, 1981, 20, 9, 582-584.

25. Roelands, R, Diagnosis and treatment of solar urticaria, Dermatol Ther, 2003, 16 (1), 52- 6.

26. Sigurgeirsson, B, Skin disease and malignancy. An epidemiological study, Acta Derm Venereol Suppl, 1992, 178, 1-110.

27. Tebbe, B, C. C. Geilen, J. D. Schulzke, C. Bojarski, Helicobacter Pylori infection and chronic urticaria, J Am Acad Dermatol, 1996, 34(4), 685-6.

28. Toossi , P, M. Rahmati, The relationship between urticaria and hepatits-C, 10-th Congress of European Academy of Dermatology\& Venerology, Munich, 10-14 October 2001.

29. Tupker, R.A, H.M. Doeglas, Water vapour loss threshold and induction of cholinergic urticaria, Dermatolgica, 1990, 181(1), 23-5.

30. Valsecchi, R, P. Pigatto, Chronic urticaria and Helicobacter pylori, Acta Derm Venereol, 1998, 78(6), 440-2.

31. Volcheck, GW, J. T. Li, Axercise- induced urticaria and anaphylaxis, Mayo Clin Proc, 1997, 72 (2), 140-7. 